\title{
Kommentar
}

\section{Brystsmerter kan være så mangt}

Historien om smertefull og støyende pneumothorax som ble oversett, kunne hendt noen hver av oss. Beskrivelsen av pasienten, den diagnostiske jakten og den etterfølgende diskusjonen er mønstergyldig, selvkritisk og absolutt noe å lære av.

Fortellingen åpner for flere refleksjoner, - bl.a. over diagnostikk av pneumothorax og over når det er trygt å fly med/eller etter en pneumothorax.

Nagarsheth \& Kurek fant at røntgen thorax hadde en sensitivitet for påvisning av pneumothorax på bare $32 \%$ sammenliknet med CT, mens ultralydundersøkelse med sine $82 \%$ var langt bedre (1). Påviser man luftkappen ved vanlig røntgen thorax, er saken klar. Ser man den ikke, er det ikke nødvendigvis greit. Siden CT også kan avsløre en rekke andre potensielt farlige tilstander relatert til brystsmerter i tillegg til pneumothorax, burde vel CT thorax i dette tilfellet vært tatt som en del av den initiale diagnostikken.

Pasienten hadde liknende symptomer som bedret seg spontant ca. to uker forut for innleggelsen. Vi kan vel gjette på at han da hadde $\sin$ første luftlekkasje til pleura som så lukket seg spontant inntil han på ny fikk symptomer og ble innlagt. Kort tid etter utskrivningen gjennomførte han en lengre flyreise og ikke lenge etter ankomst fikk han brystsmerter på nytt, og det ble da påvist en pneumothorax. Residivfrekvensen er høy etter første gangs pneumothorax, omkring $40 \%$ (2). Det er sannsynlig at flyturen har spilt en rolle, - men ikke sikkert. Ved nylig gjennomgått pneumothoraxbehandling eller ved kjent høy risiko for utvikling av ny pneumothorax bør det tas et røntgen thorax, og gjøres en ultralydundersøkelse med tanke på luftkappe før flyreise. Det bør så gjøres en samlet vurdering av risikoen ved den planlagte reisen.

Både i USA og i Storbritannia er de offisielle retningslinjene for å fly med vanlig rutefly med/etter pneumothorax temmelig restriktive til tross for beskjedent kunnskapsgrunnlag (3). Szymanski og medarbeidere har beskrevet at $40 \%$ av thoraxkirurger i USA lar pasientene fly med en liten pneumothoraxkappe (3). Flyreise etter lungebiopsi med en liten iatrogen pneumothorax er nesten alltid ukomplisert (4).

Vi har ingen norske retningslinjer for dette. Ved Universitetssykehuset Nord-Norge foretrekker vi naturligvis transport til lands eller til vanns, men forutsatt tilfredsstillende lungefunksjon (5) og en mindre enn $2 \mathrm{~cm}$ stabil (siste 12 timer) kappe over lungetoppen, vil vi også overveie flytransport. Større kapper behandles eller avventes før flyging, eventuelt får pasienten reise med innlagt, fungerende thoraxdren. Ikke utfylt restvolum uten lekkasje etter fjerning av lungevev kan også aksepteres.
Dag Sørlie

dag.glen.sorlie@unn.no

Universitetssykehuset Nord-Norge

Dag Sørlie (f. 1942) er professor og overlege ved Avdeling for hjerte-, lunge- og karkirurgi. Forfatter har fylt ut ICMJE-skjemaet og oppgir ingen interessekonflikter.

\section{Litteratur}

1. Nagarsheth K, Kurek S. Ultrasound detection of pneumothorax compared with chest X-ray and computed tomography scan. Am Surg 2011; 77: $480-4$

2. Wakai A, O'Sullivan RG, McCabe G. Simple aspiration versus intercostal tube drainage for primary spontaneous pneumothorax in adults. Cochrane Database Syst Rev 2007; nr. 1: CD004479.

3. Szymanski TJ, Jaklitsch MT, Jacobson F et al. Expansion of postoperative pneumothorax and pneumomediastinum: determining when it is safe to fly. Aviat Space Environ Med 2010; 81: 423-6.

4. Tam A, Singh P, Ensor JE et al. Air travel after biopsy-related pneumothorax: is it safe to fly? J Vasc Interv Radiol 2011; 22: 595-602.e1.

5. Akerø A, Christensen CC, Edvardsen A et al. Pulse oximetry in the preflight evaluation of patients with chronic obstructive pulmonary disease. Aviat Space Environ Med 2008; 79: 518-24.

Mottatt 25.4. 2012, første revisjon innsendt 20.6. 2012, godjent 3.7. 2012. Medisinsk redaktør Kristin Viste. 